\title{
Thymic Squamous Cell Carcinoma
}

National Cancer Institute

\section{Source}

National Cancer Institute. Thymic Squamous Cell Carcinoma. NCI Thesaurus. Code C6455.

A rare primary thymic carcinoma, characterized by the presence of keratinizing or nonkeratinizing malignant squamous cells. Approximately 10-20\% of cases occur in combination with thymoma. The prognosis depends on the tumor stage and the degree of cellular differentiation. 